\title{
副咽頭間隙に転移をさたした甲状腺癌例
}

\author{
服部 賢二・岩田 伸子・奥山 晃子 \\ 中川崇・宮崎 裕子

\section{Thyroid Carcinoma Metastatic to the Parapharyngeal Space} \\ Kenji Hattori, Nobuko Iwata, Akiko Okuyama, \\ Takashi Nakagawa and Yuko Miyazaki \\ (Sumitomo Hospital)

\begin{abstract}
The parapharyngeal space is a complex area where a variety of both primary and metastatic neoplasms can originate. Metastatic lymph nodes in this region are common in pharyngeal squamous cell carcinoma. However it is a rare clinical occurrence that a metastatic thyroid carcinoma occupies the parapharyngeal space. We reported a 58-year-old male who had been operated upon for a thyroid carcinoma at 44 years of age and had a large metastatic lymph node in the right parapharyngeal space. We removed the metastatic lymph node by the mandibular swing-transcervical approach. Rouviere described a direct lymphatic pathway from the posterior surface of the superior thyroid lobe to lateral retropharyngeal lymph nodes. The possibility must be considered that thyroid carcinoma existing in that particular region can metastasize to the parapharyngeal space.
\end{abstract}

Key words : thyroid carcinoma, metastasis, parapharyngeal space

はじめに

副咽頭間隙は解剖学的に複雑で，この間隙を占める腫 瘤は組織学的に多彩である.そのなかで, この部位にあ る外側咽頭後リンパ節への転移は咽頭癌などに㧊いて認 められるが，甲状腺癌からの転移はまれである．今回わ れわれは，長期間を経て副咽頭間陌を占める巨大なリン パ節転移をきたした甲状腺癌の 1 例を経験したので，若 干の文献的考察を加えて報告する.

\section{症例}

患者 : 58歳, 男性.

主訴 : 軟口蓋右側の腫瘤.

既往歴: 昭和 59 年, 44歳の時, 甲状腺乳頭癌のため他 院で甲状腺亜全摘出術, 右頸部郭清術(甲状腺癌取扱い 規約1)でレベル I〜VII, 対側レベル III)を受けていた.
腫瘍は甲状腺右葉全体を占め, 前頸筋へ被膜外浸潤が あった.リンパ節転移は同側レベルIII，Va に認められ， pT4N1aM0であった。

現病歴 : 平成 10 年 8 月に感冒罹患のため近医を受診し た際, 軟口蓋の腫瘤を指摘され, 当科を紹介された. 自 覚症状はなかった. 初診時, 軟口蓋右側粘膜下に表面平 滑, 弾性軟の腫瘤を認めた。脳神経および交感神経の脱 落症状はなかった. な拉, 平成 3 年 11 月以降当科受診ま で，転居を期にどこにも本人が受診していなかった。

検査所見：残存甲状腺には触診, CT, エューいずれ も異常を認めなかった. 軟口蓋腫瘤の穿刺細胞診は, class N であった. MRI で右副咽頭間隙に椎前筋执よ び内側翼突筋と境界が一部不明瞭で, 内部不均一，頭蓋 底にまで達する腫瘍が認められた（図 1 )。 また，腫瘍は ガドリニウムによる造影効果が認められた. デシタル血 


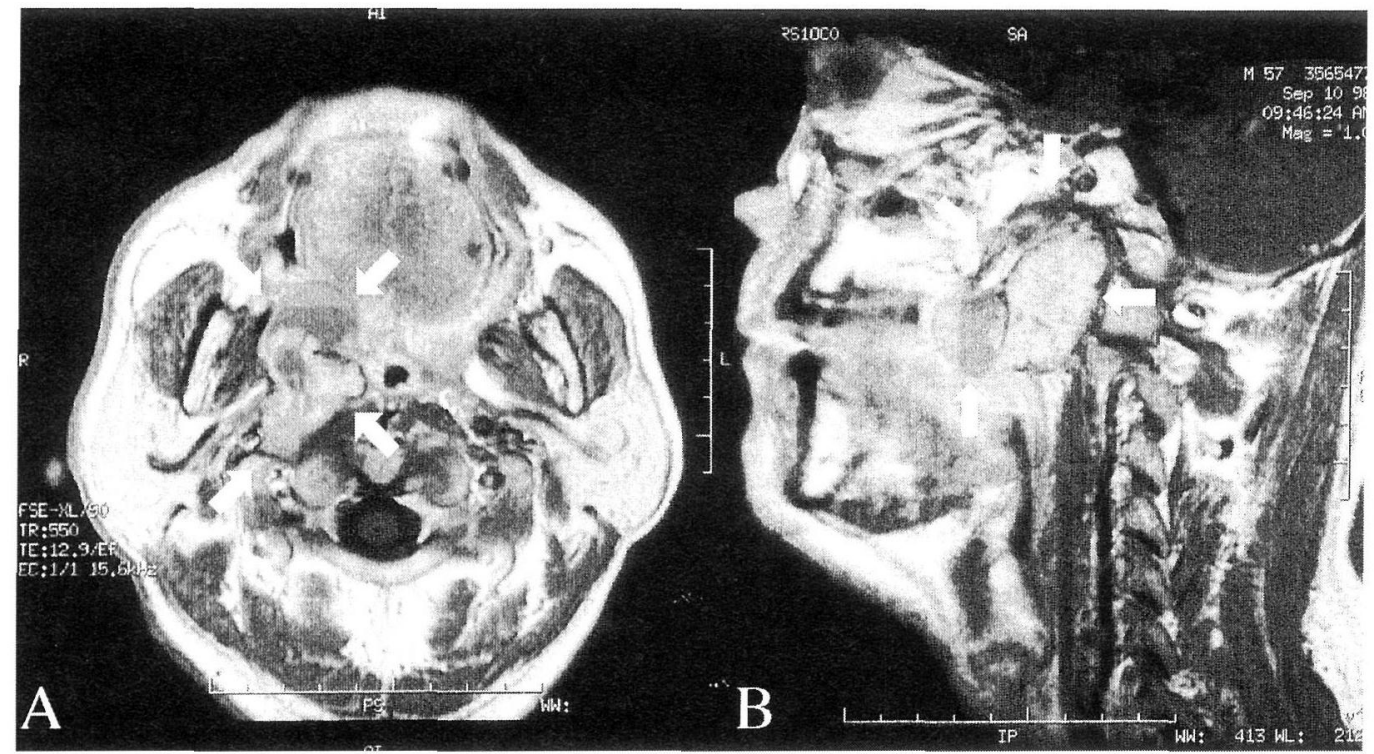

図1 MRI T1 ガドリニウム造影像

$\mathrm{A}$ : 軸位断 $\mathrm{B}$ : 矢状断

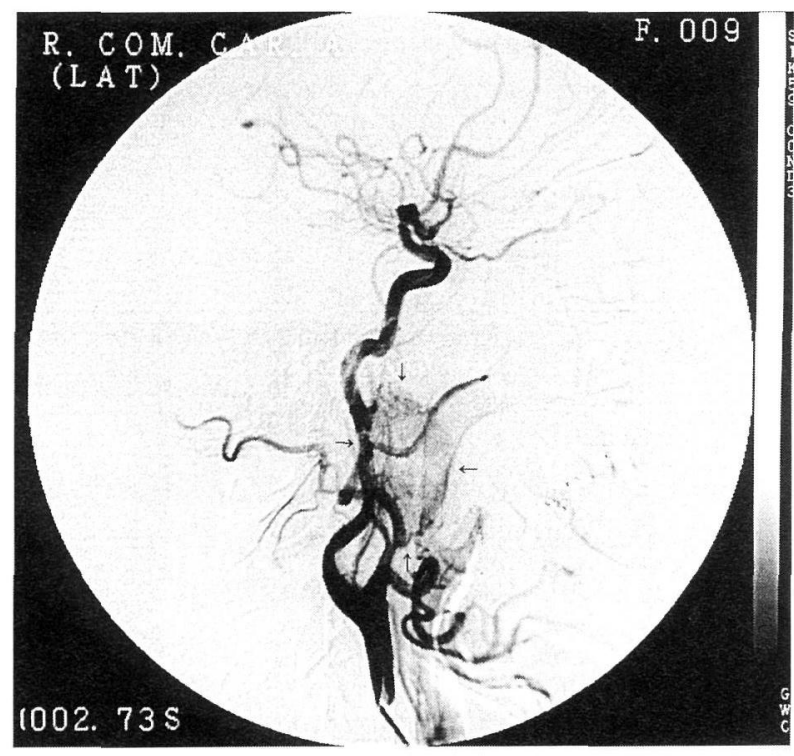

図 2 デジタル血管造影

腫瘍はわずかに造影され，その栄養血管は上行咽頭動脈 であった。

管造影(図 2 ) で腫瘍はわずかに造影され，その栄峑血管 は上行咽頭動脈であったが，血流は豊富ではなく塞检術 は行わなかった。また，放射性ヨウ素の集積は認められ なかった。
手術持よび病理結果：平成10年10月 1 日，右顎下部 (レベルVI) 郭清を施行後, mandibular-swing 法にて副 咽頭間隙に達し腫瘍摘出術を行った. 腫瘍と脳神経, 交 感神経との関連は認められず, これらを保存し, 椎前筋 执よび内側翼突筋の一部は合併切除した。病理組織学的 検査で，44歳時の甲状腺乳頭癌の病理組織像 (図 $3 \mathrm{~A}$ ) と 同様に摘出標本で，高度に分化した乳頭状構造の増殖括 よび一部濾胞状構造を認めた（図 3 B)，东た核には，す りガラス状核, 核の溝, 核内細胞質封入体を認め, 甲状 腺乳頭癌の外側咽頭後リンパ節転移と診断した.

\section{考察}

副咽頭間隙に扣ける腫瘤は, 腫瘍性病変と非腫瘍性病 変に大別され, 腫瘍性病変はさらに原発性と続発性に分 類される。同部位の腫瘍は頭頸部腫瘍の $0.5 \%$ を占め2), その $80 \%$ は良性である3). 腫瘍は原発性では神経原性腫 瘍が, 続発性では唾液腺腫瘍が最も多く4), その他, 咽 頭腫瘍の浸潤, 悪性腫瘍の転移がある.今回の例は外側 咽頭後リンパ節に転移した甲状腺癌が長期間を経て巨大 化し副咽頭間陌を占めた症例であった。

甲状腺乳頭癌は一般的には予後がよいとされているが， 初診時に頸部リンパ節転移を認める症例は，乳頭癌では 61\%であり ${ }^{5}$ ，転移症例の36\%にレベル II〜 Vの頸部リ 


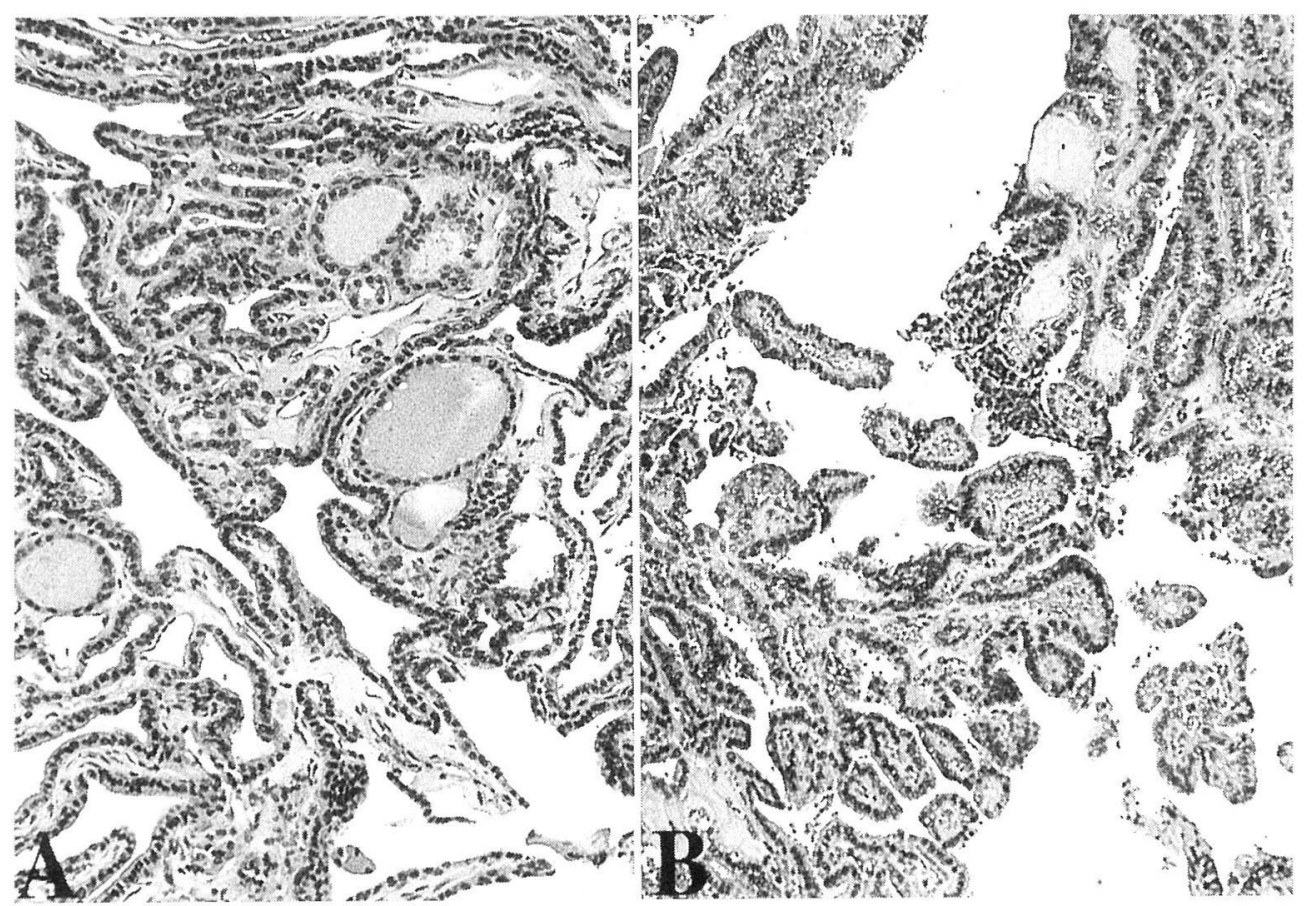

図 3 病理組織像

A : 44歳時摘出した甲状腺乳頭癌 $(\mathrm{HE}$ 染色, $\times 25)$

$\mathrm{B}$ : 摘出した咽頭後リンパ節 $(\mathrm{HE}$ 染色, $\times 25)$

高度に分化した乳頭状構造の増殖执よび一部濾胞状構造を認めた。核にはすりガラス状

核, 核の溝, 核内細胞質封入体を認め, 甲状腺乳頭癌の外側咽頭後リンパ節転移と診断 した.

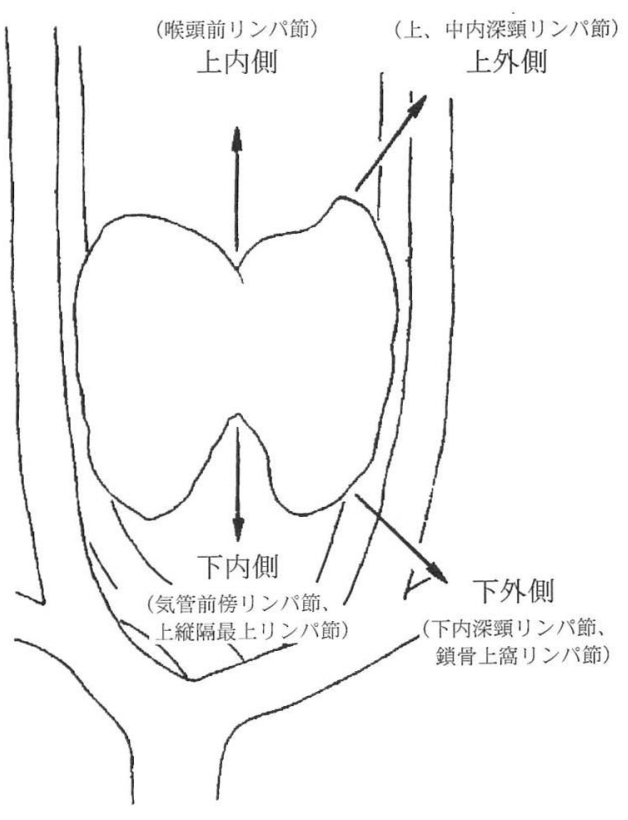

図 4 甲状腺からのリンパ流出経路

(Robbins TK, et al : 19859) より改変)
ンパ節に多発転移を認める6). N0 と N1 の 20 年後の疾患 特異的生存率はそれぞれ92\%执よび93\%で差はないが， $\mathrm{N} 1$ 症例は再発率が高い傾向にあり，また45歳以上に限 ると N1 症例が有意に予後が悪い7)。 またShaha 5 8)の 報告では，4\%に初診時から遠隔転移があり，転移のな い症例の 5 年生存率が $86 \%$ であのに対し，転移のある 症例の 5 年生存率は $43 \%$ である.

以上のことから，頸部リンパ節転移を初㡎時より認め る甲状腺乳頭癌は，少なくともレベル II 亿の頸部郭清 が必要である、レベルII〜Vの郭清では副神経, 頸神経 は保存でき, 永久的合併症は少ないものと考光る。

甲状腺には多くのリンパチャネルがあるが, 主に 4 つ の経路9) がある(図 4). 甲状腺から上方へのリンパ流出 路は上甲状腺動脈に沿って流出乙, 頸動脈分岐部付近へ のリンパ節に流入する。また，正中では喉頭前リンパ節 に流入する.下方へは下甲状腺静脈に沿い, 気管前, 気 管傍リンパ節に流入し, さらに下方に流れ, 下内深頸リ ンパ節，鎖骨上窩リンパ節に流れる.甲状腺より直接鎖 
骨上裔リンパ節に流入する経路もある. 通常, 甲状腺癌 に扎いて重要なリンパ節は, 内深頸リンパ節と気管前, 傍リンパ節である ${ }^{10)}$. しかし Rouviere ${ }^{11}$ により，解剖 例の $20 \%$ で甲状腺から咽頭後リンパ節へ直接流れるリン パ流があることが報告されている。この経路は甲状腺外 側で上極, なかでも後面に端を発している9（図 5 )。し たがって，この部位に癌が存在する場合には咽頭の外側 を上行し, 咽頭後リンパ節に転移する可能性があり注意 を要する. また, 被膜外浸潤があり咽頭収縮筋, 椎前筋 への浸潤を認める場合は，当然咽頭後リンパ節への転移 の可能性は高くなるものと考兄る. 文献的にも咽頭後リ ンパ節への転移の報告が散見され，McCormack ら ${ }^{12)}$ は 甲状腺癌の咽頭後リン八゚節への転移例を 313 例中 7 例に 認めたことを報告している．これらの症例の予後は 1 例 を除き発症後 $2 \sim 29$ 年, 咽頭後リンパ節に転移が判明し て後 7 カ月から 8 年で死亡している. 死亡原因は頭蓋内 進展 3 例, 咽頭への出血 1 例などで, 他臟器への転移が なく，頭蓋内進展，大血管への浸潤がない症例であれば 咽頭後リンパ節転移は積極的に手術するべきものと考兄 た。

甲状腺乳頭癌は増大速度が一般的に遅い悪性腫瘍であ り，予後も比較的よいとされている。しかしながら癌で ある限り長期観察で再発, 転移も生じ得ること, また,

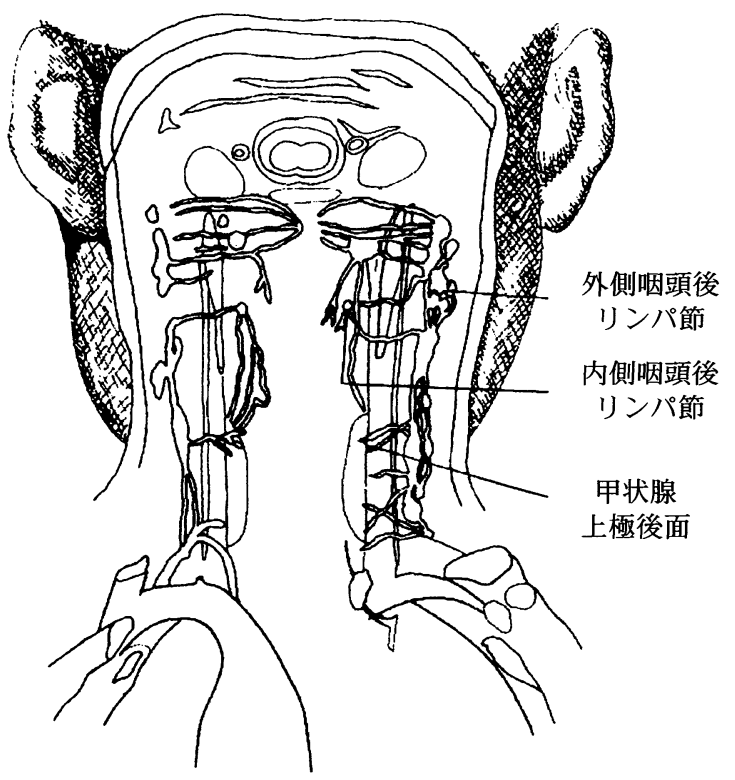

図 5 咽頭後リンパ節へのリンパ流 (Robbins TK, et al : 19859) より改変)
副咽頭間隙の腫瘤は大きくなるまで自覚症状に乏しく見 落としやすいことから, 甲状腺外側で上極に癌が存在す る場合は, 術前および経過観察時に咽頭後リンパ節への 転移に十分注意する必要がある。

$$
\text { まとめ }
$$

長期間を経て副咽頭間隙を占める巨大なリンパ節転移 をきたした甲状腺癌の 1 例を経験した. 甲状腺外側で上 極, なかでも後面に癌が存在する場合には外側咽頭後り ソパ節に転移する可能性があり, 治療, 経過観察の際注 意する必要がある。

本論文の要旨は第61回耳鼻咽喉科臨床学会(1999年, 大分)に おいてロ演した。

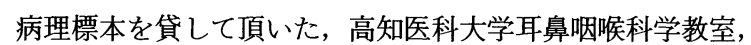
中谷宏章先生に感謝いたします。

\section{参考文献}

1) 甲状腺外科検討会: 甲状腺癌取扱い規約(甲状腺外科検討 会編). 5 9 頁, 金原出版, 東京, 1996.

2) Carrau RL, Myers EN and Johnson JT : Management of tumors arising in the parapharyngeal space. Laryngoscope $100: 583 \sim 589,1990$.

3 ) Lawson VG, LeLiever WC, Makerewich LA, et al : Unusual parapharyngeal lesions. J Otol $8: 241 \sim 249,1979$.

4 ) Hughes KV, Olsen KD and McCaffrey TV : Parapharyngeal space neoplasms. Head Neck $17:$ 124 130, 1995.

5 ) Shaha AR, Shah JP and Loree TR : Patterns of nodal and distant metastasis based on histologic varieties in differentiated carcinoma of the thyroid. Am J Surg $172: 692 \sim 694,1996$.

6 ) Ducci M, Appetecchia M and Marzetti M : Neck dissection for surgical treatment of lymphnode metastasis in papillary thyroid carcinoma. J Exp Clin Cancer Res 16 : 333 335, 1997.

7 ) Hughes $\mathrm{CH}$, Shaha AR, Shah JP, et al : Impact of lymph node metastasis in differentiated carcinoma of the thyroid ; a matched-pair anarysis. Head Neck 18 : 127 132, 1996.

8 ) Shaha AR, Shah JP and Loree TR : Differentiated thyroid cancer presenting initially with distant metastasis. Am J Surg $174:$ 474 476, 1997.

9 ) Robbins TK and Woodson GE : Thyroid carcinoma presenting as a parapharyngeal mass. Head Neck 7 : 434 436, 1985.

10）河西信勝: 甲状腺からのリンパ路. 甲状腺切除のテクニッ クと患者管理. 23～27頁, 医学書院, 東京, 1991. 
11) Rouviere $\mathrm{H}$ : Anatomy of the human lymphatic system ; a compendium translated from the original and rearranged for the use of students and practitioners by M.J. Tobias and J.W. Edwards. Ann Arbor, Michigan, 1938.

12) McCormack KR and Sheline GE : Retropharyngeal spread of carcinoma of the thyroid. Cancer $26: 1366 \sim 1369$, 1970.
原稿受付：平成12年 3 月 16 日 原稿採択 : 平成 12 年 5 月 10 日 別刷請求先 : 服部賢二

厂530-0005 大阪市北区中之島5-2-2

(財)住友病院耳鼻咽喉科 